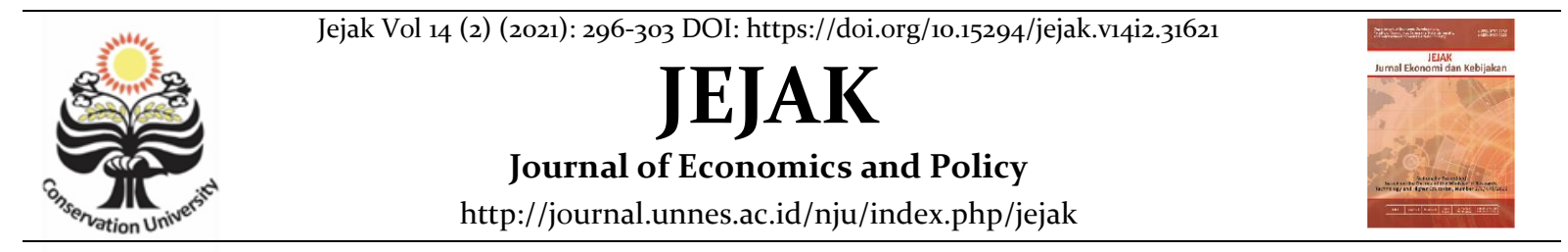

\title{
Decision Making and Patronage Behaviour in Islamic Co-operatives in Aceh, Indonesia
}

\author{
M. Shabri Abd. Majid ${ }^{1 凶},{ }^{2}$ Faisal Faisal, ${ }^{3}$ Heru Fahlevi, ${ }^{4}$ Hafasnuddin \\ 1,2,3,4Faculty of Economics and Business, Universitas Syiah Kuala, Banda Aceh, Indonesia \\ Permalink/DOI: https://doi.org/10.15294/jejak.v14i2.31621 \\ Received: May 2021; Accepted: July 2021; Published: September 2021
}

\begin{abstract}
Although the number of Islamic co-operatives' memberships only amounted to 2.51 million people (11.19\%) to the total membership of co-operatives in Indonesia nationwide, but it has shown a rising trend in its membership by 76.11\% over the last decade (Ministry of Co-Operatives \& SMEs, 2019). These figures raise an essential research question: what drives the decision of Indonesian citizens to patronage Islamic co-operatives? Specifically, this study explores pertinent determinants of decision-making made by the members to select Islamic co-operatives in Aceh, Indonesia. A number of 280 members and nonmembers of Islamic co-operatives were selected as the sample of the study using a purposive sampling technique. Based on the logistic multiple regression technique, the study recorded that the members' decision-making in selecting Islamic co-operatives was mainly determined by their shari'ah compliance and characteristics' uniqueness. Meanwhile, physical facilities and services quality provided by the Islamic co-operatives have insignificant effects on the people's decision-making to become the memberships of Islamic co-operatives. This empirical evidence suggested that to attract more memberships, the Islamic co-operatives should improve their shari'ah compliance and characteristics' uniqueness.
\end{abstract}

Key words: Decision making, Patronage behavior, Islamic co-operative, Shari'ah compliance, Logistic regression.

How to Cite: Majid, M., Faisal, F., Fahlevi, H., \& Hafasnuddin, H. (2021). Decision Making and Patronage Behaviour in Islamic Co-operatives in Aceh, Indonesia. JEJAK: Jurnal Ekonomi dan Kebijakan, 14(2). doi:https://doi.org/10.15294/jejak.v14i2.31621 


\section{INTRODUCTION}

In the last decade, one in each of six residents on the globe is co-operators. Globally, the membership of co-operatives has reached at least 800 million people. The top 300 co-operatives on the globe have created jobs for no less than 280 million people worldwide, contributing to USD2.1 trillion of global co-operatives' turnover (International Co-operative Alliance, 2017). This shows the crucial role of co-operatives to worldwide social-economic development (Hasan, Azhari, \& Majid, 2018), including Indonesia.

In Indonesia, the 1945 Indonesian Constitution has mandated co-operatives as the backbone and pillar of the national economy (Majid, et al., 2020a). The launch of the Savings and Loan Co-operative in 1896 in Purwokerto City, Central Java, which is mainly aimed to free the farmers from moneylenders (Nasution, 2007) has marked the first establishment of co-operative in the country's co-operative history. Since then, many co-operatives have emerged into many economic sectors nationwide (Majid, et al., 202ob). Following the appearance of Islamic financial and banking institutions in the Muslim world in the 1970 s and the first establishment of an Islamic bank in Indonesia, Bank Muamalat Indonesia (BMI), similar demand has emerged for the presence of co-operatives that are operated based on Islamic tenets (Sakai, 2010; Majid \& Hasin, 2014). In their operation, Islamic cooperatives must be free of elements of usury (riba), uncertainty (gharar), and gambling (maysir).

In response to the high demand for the emergence of Islamic co-operatives, the Ministry of Co-operatives and Small and Medium Enterprises (SMEs) of the Republic of Indonesia has issued State Decree No. 91/2004 concerning Guidelines for Islamic
Financial Services Cooperative Business Activities. Since the last three decades, many Islamic co-operatives have been operating in parallel with the conventional co-operatives in Indonesia. In 2019, of 123,048 co-operatives in Indonesia, 4,046 (3.29\%) of them were Islamic co-operatives. Comparing to the number of members of conventional co-operatives that reached 22.46 million people in 2019, the Islamic co-operatives memberships only amounted to 2.51 million people or $11.19 \%$ to the total membership of co-operatives nationwide (Ministry of Co-Operatives \& SMEs, 2019).

In the last decades, the membership of conventional co-operatives has shown a decreasing trend, while a rising trend is experienced by the membership of Islamic cooperatives. The number of conventional cooperatives memberships has declined by $\mathbf{2 3 . 1 7 \%}$ over the 2009-2019 period, while the number of members of Islamic co-operatives has increased by $76.11 \%$ over a similar period (Ministry of Co-Operatives \& SMEs, 2019). These figures raise an essential research question: what drives the decision of Indonesian citizens to patronage Islamic cooperatives?

Previous studies on Muslim preferences have been intensively focused on Islamic banking and the financial industry worldwide. The Islamic preferences to Islamic banking and financial institutions have been conducted in Malaysia (Abdelghani \& Oladokun, 2012), Jordan (Naser, Jamal, \& Al-Khatib, 1999), Bangladesh (Hassan, Khan, \& Shahid, 2007), Bahrain (Al-Ajmi, Hussain, \& Al-Saleh, 2009), Thailand (Lateh, Ismail, \& Ariffin, 2009), the UK (Walid, et al., 2010), and Indonesia (Majid \& Zulhanizar, 2016).

The above-reviewed studies documented that both internal and external factors affected the decision of customers to select the banking 
institution. Macroeconomic factors such as income, regulation, interest rate, etc., and internal factors such as psychological, education, services and facilities, religious commitment, and product innovation have differently influenced the decision of the customer to patronage Islamic banking and financial institutions. Do similar factors affect the decision of customers to select other Islamic non-banking financial institutions, such as Islamic co-operatives? If yes, to what extent do those factors influence the customers' decision to select Islamic cooperatives?

Realizing the inexistence of similar previous studies on the determinants of decision making of people to patronage Islamic co-operatives, thus, this research intends to fill those gaps by taking the case of Islamic co-operatives in Indonesia. Additionally, considering the operation of Islamic institutions such as co-operatives should comply with the shariah principles (Ahmad \& Al-Aidaros, 2015), thus this study incorporate shari'ah compliance - a factor ignored by many previous studies - as one of the crucial determinants of the decision in selecting Islamic co-operatives in Indonesia.

Specifically, this study explores the effects of shari'ah compliance, co-operative characteristics, physical facilities, and services quality on the decision of Indonesian in becoming Islamic co-operative membership.

The study's findings are hoped to offer some policy references for the management of Islamic co-operatives in designing policy to attract more memberships, and for government to design a policy to enhance the presence and contribution of Islamic cooperatives to promote the welfare of Indonesian citizens nationwide.

The remaining parts of the paper are structured in the following manner. Section 2 discusses the research method and data on which the analysis is conducted. Section 3 provides the findings, discussions, and implications. Finally, the conclusion is presented in the last section.

\section{METHOD}

According to Regulation No. 16 (2015) of the Ministry of Co-operatives and SMEs, the Republic of Indonesia, Islamic co-operative is "a non-banking institution whose business activities include savings, loans, and financing following shari'ah principles, including managing zakat, infaq, and waqf". Its activities should uphold the fundamental objectives of shari'ah (Maqashid as-Shari'ah), comprising five basic protections: life (an-Nafs); religion (adDin); lineage (an-Nasl); intellectual (al-'Aql); and wealth (al-Mal) (Majid \& Kassim, 2015). Thus, the products and services offered by Islamic co-operatives should be free from riba, gharar, and maysir (Itam, Hasan, \& Alhabshi, 2016), thus in harmony with Maqashid Shari'ah.

This research empirically probes the effects of shari'ah compliance, characteristics, physical facilities, services quality on the decision of people in patronaging Islamic cooperatives in Banda Aceh City, Indonesia. A number of 280 respondents, comprising 140 members of Islamic co-operative members and 140 non-members of Islamic co-operatives were selected as the study's sample using a purposive sampling technique. The members of Islamic co-operatives selected are those with ages of 16 years and above and have been an Islamic cooperative membership at least two years, while the non-members of Islamic co-operative selected are those with ages of 16 years and above. The number of selected respondents in this study is more than sufficient to represent the entire population, considering the minimum sample size of only 100 (Hair, et al., 2010). 
In this study, the dependent variable is the people's decision-making in either selecting or not selecting Islamic co-operative. The dummy variable measures the dependent variable (i.e., deciding not to select Islamic cooperative $=0$; deciding to select Islamic cooperative = 1). Meanwhile, the four independent variables are investigated in the study, comprising shari'ah compliance, physical facilities, characteristics, and services quality. Shariah compliance is defined as the assurance of the Islamic co-operatives to offer shariah compliant products and services (Seibel, 2007).

Furthermore, physical facilities are defined as the personnel, equipment, and communication facilities of the co-operatives (Nupur, 2010), while co-operative characteristics refer to the operation, products, and services offered based on profitloss sharing system (Bond, 2009).

Finally, services quality is defined as the ability of co-operatives to provide the promised services, establish good communication, personal attention, and understand the needs of the members (Vamstad, 2012).

All the independent variables are measured in the interval scale of the 5-point Likert-scale (i.e., strongly disagree $=1$; disagree $=2$; quite agree $=3$; agree $=4$; and strongly agree $=5$ ).

This study utilizes primary data gathered by distributing questionnaires to respondents. A 16-closed question was asked about the determinants of respondents' decision-making either in selecting or not selecting Islamic co-operatives. 4-question was asked respectively relating to the shari'ah compliance, physical facilities, and services quality, while 3-question was asked about the Islamic co-operative's characteristics.

Before the data are further analyzed using multiple logistic regression, the instrument tests of reliability and validity, and the classical assumptions of normality, heteroscedasticity, and multicollinearity were conducted using the standard techniques. After ensuring the validity, reliability, and fulfillment of classical assumptions of the data, the study estimates the following logistic multiple regression equation:

$$
\begin{aligned}
\log (\mathrm{P} / 1-\mathrm{P})= & \mathrm{DMK}=\beta_{\mathrm{o}}+\beta_{1} \mathrm{SHC} \\
& +\beta_{2} \mathrm{PFC}+\beta_{3} \mathrm{ICR}+\beta_{4} \mathrm{SRQ}
\end{aligned}
$$

Where $P$ is the probability that $D M K$ (the decision making) is equal to 1 , and $S H C$ is the shari'ah compliance, $P F C$ is the physical facilities, $I C R$ is the Islamic co-operative characteristics, $S R Q$ is the quality of the services, $\beta_{\mathrm{o}}$ is the constant term, and $\beta_{1}-\beta_{4}$ are the estimated regression coefficients.

\section{RESULTS AND DISCUSSION}

In this study, a number of 280 respondents (i.e., 140 members and 140 nonmembers of Islamic co-operatives) in the city of Banda Aceh, Indonesia were investigated their decision-making in selecting and not selecting Islamic co-operatives. Based on their characteristics, the majority of the respondents were male $(56 \%)$, with ages between 20 to 30 years old ( $34 \%$ ), university graduates (39\%), government employees (35\%), and monthly income of IDR3 million.

Table 1 further illustrates the perception of respondents on the investigated variables. As observed from Table, the respondents perceived the shari'ah compliance, physical facilities, co-operative characteristics, and services quality of the Islamic co-operatives were in the "good" category with the average score of 3.91, 3.62, 3.89, and 3.73, respectively. 
Table 1. Perception of the Respondents

\begin{tabular}{lcccc}
\hline \multicolumn{1}{c}{ Variable } & Minimum & Maximum & Mean & Standard Deviation \\
\hline Shari'ah Compliance & 2 & 5 & 3.91 & 0.607 \\
Physical Facilities & 1 & 5 & 3.62 & 0.618 \\
Co-operative Characteristics & 1 & 5 & 3.89 & 0.747 \\
Services Quality & 2 & 5 & 3.73 & 0.531 \\
\hline
\end{tabular}

After ensuring the validity and reliability of all instruments and the data satisfied the classical assumptions, the study proceeds to explore the effects of shariah compliance, physical facilities, co-operative characteristics, and services quality on the decision-making in selecting Islamic cooperatives.

Table 2 provides the findings of the estimated logistic multiple regression analysis.

Table 2. Findings of Estimated Logistic Multiple Regression Analysis

\begin{tabular}{lccc}
\hline \multicolumn{1}{c}{ Variable } & $\boldsymbol{\beta}$ & Odds Ratio & P-value \\
\hline Shari'ah Compliance & $1.353^{* * *}$ & 3.898 & 0.000 \\
Physical Facilities & 0.205 & 0.875 & 0.636 \\
Co-operative Characteristics & $0.492^{* *}$ & 1.796 & 0.049 \\
Services Quality & 0.259 & 0.903 & 0.476 \\
\hline \multicolumn{2}{c}{-2 Log Likelihood $=$ 210.402; Cox \& Snell's $\mathrm{R}^{2}=0.264 ;$ Nagelkerkes' $\mathrm{R}^{2}=0.352$} \\
\multicolumn{2}{c}{ Overall $(\%)=76.54$; Hosmer \& Lameshow Chi-Square $=5.142(\mathrm{p}$-value $=0.531)$} \\
\hline
\end{tabular}

Note: ${ }^{* * *}$ and ${ }^{* *}$ indicates $1 \%$ and $5 \%$ significant levels.

As reported in Table 2, of four independent variables, only shari'ah compliance and co-operative characteristics were documented to have a significant effect on the decision to select Islamic cooperatives. In contrast, other variables have an insignificant effect. Specifically, the shari'ah compliance is found to have a positive significant influence on the decision of people to select Islamic co-operatives at the $1 \%$ level significance with an odds ratio of 3.898. This shows that the higher the operation, products, and services of Islamic co-operatives comply with the shari'ah; the possibility of people decide to select Islamic co-operatives was 1.353 times higher as compared to their decision of not choosing Islamic co-operatives.

The positive effect of the shariah compliance on the possibility of people decide to select Islamic co-operatives could partially be due to the practices of profitsharing, contracts adopted, services provided, and Islamic co-operative operations have been running in harmony with the Islamic business (mu'amalah) principles (Majid \& Zulhanizar, 2016). The presence of the Shariah Advisory Board of the Indonesian Ulama Council to issue fatwa and ensure the adherence of the Islamic co-operatives to shari'ah principles has driven more Islamic co-operative memberships. Shari'ah compliance is a manifestation of all Islamic principles fulfillment in co-operatives with strong characteristics, credibility, integrity (Ahmad \& Al-Aidaros, 2015). This finding further implies that, to expand their business by attracting more memberships, Islamic co-operatives must continuously improve their operations, products, and services to comply with shari'ah principles. 
Table 2 also shows that co-operative characteristics have a significant positive effect on the people's decision to select Islamic co-operatives at the $5 \%$ level with an estimated odds ratio of 1.796 . This finding signifies that with the higher uniqueness of the Islamic co-operatives in terms of their products and services the possibility of people's decision to become members of Islamic co-operatives would be higher by 1.796 times as compared to the non-selection of Islamic co-operatives. To become a member of a co-operative, a prospective member would observe the co-operativerelated characteristics, particularly the uniqueness of its offered products and services. Thus, to attract more memberships, the Islamic co-operatives should continuously enhance the uniqueness of their characteristics distinguished themselves from conventional co-operative counterparts.

Unlike the shariah compliance and cooperative characteristics, the physical facilities and services quality of the Islamic co-operatives have insignificant influences on the people's decision to become memberships of Islamic co-operatives. This might be, inter alia, caused by the attraction of co-operatives' members to shari'ah compliances and the uniqueness of the co-operatives. As long as their operating is in line with the Islamic principles, they tend to pay no attention to their facilities and quality services. Islamic cooperatives are viewed to offer tremendous benefits over other conventional cooperatives both financially and spiritually. These superiorities of Islamic co-operatives are the main reason for the people's decision to become members of Islamic co-operatives.

In addition, the lack of insignificant influence of the physical facilities and service quality on the people's decision to become memberships of Islamic co-operatives might be contributed by similar limited physical facilities and relatively low level of service quality provided by Islamic co-operatives in Aceh, Indonesia. Islamic co-operatives are included in the category of the Micro, Small, and Medium Enterprises (MSMEs), which have limited physical facilities and commonly manage and operate in traditional ways.

Many Islamic co-operatives in Aceh, Indonesia have not implemented good cooperative governance principles as their management members comprise less-skilled laborers and work as part-time employees as side jobs (Majid, et al., 202ob). The majority of Islamic co-operative management members have their own job either as government employees or own businesses. In addition, the lack of adoption of advanced technological facilities in Islamic co-operatives has contributed to the low level of services quality offered by Islamic co-operatives to their members. These existing conditions contributed to the insignificant effect of physical facilities and services quality of Islamic co-operatives to attract their memberships.

Finally, referring to the last row of Table 2, overall, the variables of shariah compliance, co-operative characteristics, physical facilities, and service quality are found to explain the variation in the possibility of people's decision to become the Islamic co-operative memberships by $35.20 \%$, as shown by the Nagelkerke's $\mathrm{R}^{2}$. Meanwhile, the rest $64.80 \%$ variations in the decision to select Islamic cooperatives are described by other than the determinants investigated in our study. These include co-operative good governance principles, social and economic factors, regulation, etc. Our research also recorded the value of an overall percentage of 73.54 , showing the ability of our proposed model to forecast by $73.54 \%$ of the true condition correctly. Finally, the estimated model is documented to be a good fit enough and did not suffer from the misspecified model, as shown by the insignificance of the Hosmer and Lemeshow 
test $(0.531>0.10)$. These findings further confirm the robustness of our empirical findings, thus they could provide a better inference for designing appropriate policies to promote Islamic co-operatives as the best choice for Muslim society.

\section{CONCLUSION}

This study empirically assessed the pertinent determinants of people's decision to become Islamic co-operatives' membership. Using a number of 280 respondents and logistic multiple regression technique, the study documented that the shariah compliance and co-operative characteristics have a significant positive influence on the probability of people's decision to become the memberships of Islamic co-operatives in Aceh Province, Indonesia. Meanwhile, the physical facilities and services quality have an insignificant effect on the decision to become the memberships of Islamic co-operatives. These empirical findings imply that to capture more memberships, the Islamic co-operatives should improve their shariah compliance and unique characteristics. The Islamic cooperatives should meet the expectations of members to fully adopt Islamic principles in their operation, products, and services.

To provide more robust and comprehensive empirical findings, future studies on this issue might incorporate both external and internal determinants of people's decision in patronaging Islamic co-operative institutions, cover more Islamic co-operatives across 34 provinces nationwide, and adopt the various advanced analysis of fuzzy models.

\section{ACKNOWLEDGEMENTS}

This article is part of the research project funded by the Directorate General of Strengthening Research and Development,
Ministry of Research, Technology and Higher Education, the Republic of Indonesia, under the scheme of the World Class Research No: 215/SP2H/LT/DPRM/2019.

\section{REFERENCES}

Abdelghani, E. \& Oladokun, N. (2012). Malaysian consumers' preferences for Islamic banking attributes. International Journal of Social Economics, 39(11), 859874 .

Ahmad, M. R. \& Al-Aidaros, A. H. (2015). The need of independent shariah members in Islamic co-operative banks: an empirical study of professional accountants in Malaysia. International Review of Management and Business Research, 4(1), 110-125.

Al-Ajmi, J., Hussain, H., \& Al-Saleh, N. (2009) 'Clients of conventional and Islamic banks in Bahrain, how they choose which bank to patronize', International Journal of Social Economics, 36(11), 1086-112.

Bond, J. K. (2009). Co-operative financial performance and board of director characteristics: A quantitative investigation. Journal of Cooperatives, 22(1), 1-25.

Hair, et al. (2010). Multivariate Data Analysis. Englewood Cliffs: Prentice-Hall.

Hasan, I., Azhari, A., \& Majid, M. S. (2018). How efficient and productive are cooperatives in Indonesia? Empirical evidence from data envelopment analysis. Revesco-Revista De Estudios Cooperativos, 128, 149-172.

Hassan, M., Khan, M., \& Shahid, A. (2007). Banking behaviour of Islamic bank customers in Bangladesh. Journal of Islamic Economics, Banking and Finance, 3(2), 160-194. 
International Co-operative Alliance (2017). International Co-operative Alliances', in The 6th Annual World Co-operative Monitor: International Co-operative Alliance's 2017 Global Conference and General Assembly. Kuala Lumpur.

Itam, M. I., Hasan, R. B., \& Alhabshi, S. M. (2016). Shariah governance framework for Islamic co-operatives as an integral social institution in Malaysia. Intellectual Discourse, 24, 477-500.

Lateh, N., Ismail, S., \& Ariffin, N. M. (2009). Customers' perceptions on the objectives, characteristics and selection criteria of Islamic bank in Thailand', Gadjah Mada International Journal of Business, 11(2), 167-189.

Majid, et al. (2020a). Do Capital and Business Volume Matter for Productivity of the Cooperatives in Indonesia?. Binus Business Review, 11(1), 1-8.

Majid, et al. (2020b). The Role of CoOperatives in Labor Absorption in Indonesia. in Proceedings Aceh Global Conference-Business, Economics, and Sustainable Development Trends. Banda Aceh, Indonesia, 105-110.

Majid, M. S. A. \& Hasin, Z. (2014). Islamic banks and monetary transmission mechanism in Malaysia. Journal of Economic Cooperation and Development, 35(2), 137-166.

Majid, M. S. A. \& Kassim, S. H. (2015). Assessing the contribution of Islamic finance to economic growth: empirical evidence from Malaysia', Journal of Islamic Accounting and Business Research, 6(2), 292-310.

Majid, M. S. A. \& Zulhanizar, S. (2016). The Patronage Behaviour of Islamic Bank's Customers: empirical studies in Aceh. Al-Iqtishad: Jurnal Ilmu Ekonomi Syariah, 8(2), 201-212.

Ministry of Co-Operatives \& SMEs (2019). Annual Report. Jakarta: Kemenkop \&
UMKM.

Naser, K., Jamal, A., \& Al-Khatib, K. (1999). Islamic banking: a study of customer satisfaction and preferences in Jordan. International Journal of Bank Marketing, 17(3), 135-151.

Nasution, M. (2007) Co-operative Economic Democracy [Demokrasi Ekonomi Koperasi]. Jakarta: PIP Publishing.

Nupur, J. M. (2010). E-banking and customers' satisfaction in Bangladesh: An analysis, International Review of Business Research Papers, 6(4), 145-156.

Sakai, M. (2010). Growing together in partnership: Women's views of the business practices of an Islamic Savings and Credit Cooperative (Baitul Maal wat Tamwil) in Central Java, Indonesia. in In Women's Studies International Forum. Pergamon., 412-421.

Seibel, H. D. (2007) Islamic Microfinance: The Challenge of Institutional Diversity. 5.

Vamstad, J. (2012). Co-production and service quality: The case of co-operative childcare in Sweden. Voluntas: International Journal of Voluntary and Nonprofit Organizations, 23(4), 1173-1188.

Walid, et al. (2010). Islamic banking and customers' preferences: the case of the UK. Qualitative Research in Financial Markets, 2(3), 185- 199. 